\title{
Gemcitabine: Progress in the Treatment of Pancreatic Cancer
}

\author{
Volker Heinemann \\ Klinikum Grosshadern, III Medical Clinic, Munich, Germany
}

\section{Key Words \\ Clinical benefit response - Combination therapy Gemcitabine · Palliative chemotherapy · Pancreatic cancer $\cdot$ Single agent $\cdot$ Tumor marker}

\begin{abstract}
Unresectable pancreatic cancer has a dismal prognosis with a median survival of 3-5 months in untreated disease. Since the introduction of gemcitabine, pancreatic cancer may no longer be regarded a chemotherapyresistant tumor. Treatment with single-agent gemcitabine achieved clinical benefit and symptoms improvement in $20-30 \%$ of patients. While 1-year survival was observed in $2 \%$ of 5 -fluorouracil (5-FU)-treated patients, it was raised to $18 \%$ by single-agent gemcitabine. Good treatment tolerability and low incidence of side effects are clear advantages of single-agent gemcitabine. Improvement of efficacy is, however, expected from combination treatment. Gemcitabine and cisplatin given as first-line treatment in three studies achieved a median survival of 7.4-8.3 months. One-year survival was raised to $28 \%$ as reported in one study. Comparable activity was obtained by a combination of gemcitabine with 5FU. Nine studies using gemcitabine in combination with standard-dose or high-dose 5-FU reported a median survival ranging from 5.5 to 13 months. Notwithstanding
\end{abstract}

\begin{tabular}{ll}
\hline KARGER & ( ) 2001 S. Karger AG, Basel \\
0030-2414/01/0601-0008\$17.50 \\
$\begin{array}{l}\text { Fax +4161306 12 34 } \\
\begin{array}{l}\text { E-Mail karger@karger.ch } \\
\text { www.karger.com }\end{array}\end{array}$ & $\begin{array}{l}\text { Accessible online at: } \\
\text { www.karger.com/journals/ocl }\end{array}$
\end{tabular}

these promising results, recommendations regarding palliative chemotherapy of pancreatic cancer remain tentative and still need confirmation by presently ongoing phase III trials. Inclusion of pancreatic cancer patients into clinical trials should be a major goal. Outside clinical trials, patients should present with an adequate PS (Karnofsky-performance index $\geq 70$ ) to qualify for chemotherapy.

Copyright $(2001$ S. Karger AG, Basel

\section{Introduction}

The incidence of pancreatic cancer has risen in recent decades. Cancer of the pancreas currently ranges between the fourth and the fifth leading cause of cancer mortality $[1,2]$. The disease primarily involves an older population with a peak incidence in the sixth decade. Tumors predominantly evolve from the exocrine pancreas and represent adenocarcinomas in $95 \%$ of cases.

The inherent dilemma of pancreatic carcinoma consists in an early systemic spread and a late diagnosis. Most of patients (85-90\%) are diagnosed at an advanced stage when curative surgery is no longer possible. Thus, the great majority of patients will eventually succumb to metastatic disease, with a median survival of 3-6 months [3]. Given this situation, an improvement of prognosis may

Volker Heinemann, MD, PhD

Klinikum Grosshadern, III Medical Clinic

Marchionini-Strasse 15, D-81377 Munich (Germany)

Tel. +49 897095 0, Fax +498970958828

E-Mail Volker.Heinemann@med3.med.uni-muenchen.de 
only be expected from an optimization of systemic treatment.

Response to chemotherapy is greatly dependent on the performance status (PS) of the patient. A Karnofsky PS $\geq 70$ was associated with a survival time more than 2 -fold longer (5.5 months) than that in patients with lower PS values (2.4 months) [4]. Disease stage is another important prognostic parameter [4], as patients with locally advanced tumors demonstrated a longer median survival (6.6 months) compared to that of patients with metastatic disease (4.4 months). Therefore, the relative risks and potential benefits of systemic chemotherapy should be weighed in each situation to ensure that patients and physicians have realistic expectations regarding treatment.

\section{Evaluation of Response in Pancreatic Cancer}

Even modern imaging techniques, such as computed tomography $(\mathrm{CT})$ or magnetic resonance imaging (MRI), frequently do not allow accurate localization and measurement of tumor extension within the adjacent tissues [2]. This is partly explained by the retroperitoneal localization of pancreatic tumors. Additionally, desmoplastic and local inflammatory reactions induced by the tumor make it difficult to differentiate between tumor and normal surrounding tissue. Differences in response between metastatic lesions and primary tumor may be explained on grounds of variable desmoplastic reactions. Tumor response may be underestimated because reactive fibrous tissue does not readily shrink during successful chemotherapy. By contrast, inflammatory reactions may be reduced more rapidly causing an overestimation of tumor response [5].

Consequently, there is not only a problem of tumor size definition at the time of diagnosis, but also a frequently inadequate estimation of tumor response when chemotherapy has been applied [6]. Conventional endpoints such as tumor response may therefore be inadequate tools for the evaluation of pancreatic cancer treatment.

\section{Endpoints of Palliative Chemotherapy in Pancreatic Cancer}

Because tumor response occurs late during treatment and may be obscured by diagnostic uncertainties, new endpoints have to be determined. Stabilization of disease should be accepted as the primary goal of palliative treatment, which can best be expressed by the combined evaluation of complete response (CR) + partial response (PR) + stable disease (SD). Even patients with SD respond to treatment and may ultimately profit from it by prolonged survival.

The determination of 1-year survival in addition to median survival appears to be a useful tool to characterize those patients who show a prolonged treatment benefit. Because there is a large amount of poorly responding pancreatic cancer patients, 1-year survival provides superior information about the responding minority.

\section{Analysis of Clinical Benefit Response as a Surrogate Parameter for Response}

A reduction of quality-of-life symptoms has gained increasing interest as a surrogate parameter of tumor response [5]. Specific attention has been given to the reduction of pain and analgesic consumption. Tumorassociated pain caused by irritation of the splanchnic nerve is a leading symptom of pancreatic cancer $(80 \%$ at first diagnosis). Clinical experience shows that small reductions of tumor size, objectively corresponding to SD, may often cause a major improvement of pain. Amelioration of tumor-associated pain often precedes the measurable reduction of tumor size and consequently serves as an early predictor of therapeutic efficacy [7].

Consequently, a number of studies have analyzed 'clinical benefit response' as a composite parameter of clinical efficacy $[8,9]$. Two primary measures were evaluated: the first measure consisted of the parameters, PS and pain; the latter being composed of pain intensity and analgesic consumption. The course of the patient's body weight was analyzed as a second measure. Clinical benefit response was then primarily evaluated using the parameters of pain and PS. Weight gain was additionally used only if a patient was considered stable by primary measures. A positive response of clinical benefit was established when a significant improvement from baseline of the respective measures was observed for an interval of at least 4 weeks: pain intensity $\leq 50 \%$, analgesic consumption $\leq 50 \%$, improvement of Karnofsky PS by $\geq 20$ points, or weight gain $\geq 7 \%$ [9]. 
Table 1. 5-Fluorouracil: efficacy in three independent randomized trials

\begin{tabular}{|c|c|c|c|c|c|c|}
\hline Reference & 5-FU regimen & $\mathrm{n} / \mathrm{eval}$ & $\mathrm{PR}, \%$ & $\mathrm{SD}, \%$ & $\begin{array}{l}\text { Survival } \\
\text { months }\end{array}$ & $\begin{array}{l}1 \text {-year } \\
\text { survival, } \%\end{array}$ \\
\hline 16 & $\begin{array}{l}500 \mathrm{mg} / \mathrm{m}^{2}, \mathrm{~d} 1-5 \\
\text { q } 5 \text { weeks }\end{array}$ & $64 / 41$ & 7 & NA & 3.5 & NA \\
\hline 8 & $600 \mathrm{mg} / \mathrm{m}^{2}$, weekly & $63 / 57$ & 0 & 19 & 4.41 & 2 \\
\hline 15 & $\begin{array}{l}500 \mathrm{mg} / \mathrm{m}^{2}, \mathrm{~d} 1-5 \\
\mathrm{q} 4 \text { weeks }\end{array}$ & $103 / 97$ & 0 & 13.4 & NA & 9 \\
\hline
\end{tabular}

$\mathrm{n} /$ eval $=$ Recruited/evaluable patients; 5-FU = 5-fluorouracil; $\mathrm{PR}=$ partial remission; $\mathrm{SD}=$ stable disease $; \mathrm{NA}=$ not available.

\section{Tumor Marker CA 19-9: A Parameter of Tumor Response}

In view of everyday decision making, analysis of surrogate constructs like quality of life (QOL), symptoms reduction, or clinical benefit are time consuming and frequently lack objectivity. Alternatively, determination of tumor marker kinetics may provide simple, fast, and reliable information on therapeutic efficacy.

The prognostic importance of CA19-9 has already been demonstrated for neoadjuvant treatment of operable pancreatic cancer [10-13]. Due to the rather low activity of chemotherapy, data have remained scarce regarding the impact of CA19-9 kinetics during palliative treatment. In a study using gemcitabine and cisplatin for palliative treatment, 20 of 21 evaluable patients presented with elevated tumor markers. All patients responding to chemotherapy with a CR or PR (8/21) demonstrated a fast and lasting reduction of CA19-9. Although the decline of CA19-9 was observed after the first treatment cycle, remissions were documented by imaging procedures only after a median of five chemotherapy courses. However, only patients reaching CR (4/21) achieved normalization of CA19-9 levels. In patients where SD was determined by imaging techniques, CA19-9 declined in all but one patient (7/8), demonstrating the biochemical efficacy of treatment without significant reduction of tumor volume. These data indicate that determination of CA19-9 may provide additional reliable evidence of response, however, a prospective, randomized trial is necessary before it is clear that CA19-9 could help guide clinical decision making and ultimately reduce the number of imaging procedures necessary. Its role in the majority of patients with pancreatic cancer who do not have an objective response to therapy, but rather may experience palliation of symptoms, also remains unclear [14].

\section{Palliative Chemotherapy: Single-Agent and Combination Regimens}

Since curative therapeutic approaches are not available, therapeutic efforts in tumor stages III and IV are mainly directed towards palliation. In the past, pancreatic cancer was rightfully considered a chemo- and radio-resistant tumor. A recent analysis of 28 phase II trials (19911994) analyzing the efficacy of 25 different agents demonstrated a median objective response rate (RR) of $0 \%$ (range $0-14.3 \%$ ), while median survival in 19 evaluable studies amounted to 3 months (range 2-8.3 months) [5]. Thus, based on these data, the benefit of chemotherapy as an instrument for disease palliation is clearly questionable.

Accordingly, a generally accepted chemotherapy regimen had not been defined for pancreatic cancer. 5-Fluorouracil (5-FU) was frequently the drug of choice when single-agent chemotherapy was used in selected patients. While high RRs in the range of $15-20 \%$ were reported in the 1970-1980s, more recent analyses, performed in the 1990 s, confirmed a median response rate of only $0-14 \%$. The true importance of 5-FU treatment may be demonstrated more adequately by an analysis of three randomized studies (table 1). Taken together, 207 patients received either single-agent 5 -FU $[8,15]$ or 5 -FU/folinic acid [16]. While two studies reported an RR of $0 \%[8,15]$, the other [16] showed a response in $7 \%$ of patients, yielding a mean remission rate for the three studies of $2.3 \%$. In two evaluable studies, median survival was 3.5 and 4.65 months, respectively, and clearly did not exceed the survival expected with best supportive care alone $[8,16]$. New agents, such as paclitaxel, docetaxel, irinotecan, topotecan, and oxaliplatin, have been tested in pancreatic cancer, but have not gained clinical importance so far. 
Table 2. Studies of gemcitabine single-agent activity in pancreatic carcinoma

\begin{tabular}{|c|c|c|c|c|c|c|c|c|c|}
\hline Reference & Phase & $\mathrm{n} / \mathrm{eval}$ & Treatment & $\begin{array}{l}\text { Gemcitabine } \\
\text { dose, } \mathrm{mg} / \mathrm{m}^{2}\end{array}$ & $\begin{array}{l}\text { PR } \\
\text { n (\%) }\end{array}$ & $\begin{array}{l}\text { SD } \\
\mathrm{n}(\%)\end{array}$ & $\begin{array}{l}\mathrm{PR}+\mathrm{SD} \\
\%\end{array}$ & $\begin{array}{l}\text { Clinical benefit } \\
\text { response } \\
\text { eval/n (\%) }\end{array}$ & $\begin{array}{l}\text { Survival } \\
\text { months }\end{array}$ \\
\hline 19 & II & $44 / 35$ & 1st-line & 800 & $5(14.3)$ & $14(40.0)$ & 54.3 & NA & 5.6 \\
\hline 18 & II & $34 / 32$ & 1st-line & 800 & $2(6.3)$ & $6(18.8)$ & 25.1 & NA & 6.3 \\
\hline 8 & III & $63 / 56$ & 1st-line & 1,000 & $3(5.4)$ & $22(39.3)$ & 44.7 & $15 / 63(23.8)$ & 5.7 \\
\hline 9 & II & $63 / 57$ & $\begin{array}{l}\text { 5-FU- } \\
\text { refractory }\end{array}$ & 1,000 & $6(10.5)$ & $17(29.8)$ & 40.3 & $17 / 63(27.0)$ & 3.9 \\
\hline
\end{tabular}

$\mathrm{n} /$ eval = Recruited/evaluable patients; 5-FU = 5-fluorouracil; $\mathrm{PR}=$ partial remission; $\mathrm{SD}=$ stable disease; $\mathrm{NA}=$ not available .

Combination regimens like FAM (5-FU, doxorubicin, mitomycin C) or SMF (streptozotocin, mitomycin C, 5FU) have induced higher RRs at the expense of greater toxicity. A prolongation of survival compared to that of single-agent 5-FU was, however, not achieved in randomized studies [3, 16].

\section{Single-Agent Activity of Gemcitabine in Advanced Pancreatic Cancer}

Gemcitabine is a pyrimidine antimetabolite [17] with good activity in various solid tumors and is presently recommended as a first-line treatment in pancreatic cancer. The typical phase II regimen of single-agent use includes a dose of 1,000-1,200 mg/m $\mathrm{m}^{2}$ given as a 30-min i.v. infusion on days 1,8 , and 15 of a 28-day cycle [3]. Gemcitabine is characterized by a low profile of side effects and accordingly by an excellent clinical tolerability.

Currently, four studies - one randomized, pivotal phase III study [8] and three phase II studies $[9,18,19]-$ are available demonstrating the clinical activity of gemcitabine in pancreatic cancer (table 2). A consequent analysis of clinical benefit response was performed in two studies $[8,9]$. Only those patients with the following were included: a Karnofsky PS $<80$, a pain intensity score $\geq 20$ $\mathrm{mm}$ (of a possible $100 \mathrm{~mm}$ according to the Memorial Pain Assessment Card), or a baseline analgesic consumption of $\geq 10 \mathrm{mg}$ morphine equivalent per day. The following conclusions may be drawn from the summary of the results of these two studies. A clinical benefit response was observed in 24 and $27 \%$, respectively, of gemcitabine-treated patients $[8,9]$ and exceeded the clinical benefit of 5-FU treatment (4.8\%) as observed in the randomized study $(p=0.0022)$ [8]. Accordingly, the median sur- vival of gemcitabine-treated patients was also significantly longer than that of the 5-FU-treated patients $(\mathrm{p}=$ 0.0025 ). After a follow-up of 1 year, $18 \%$ of gemcitabinetreated patients survived compared to $2 \%$ of $5-\mathrm{FU}-$ treated patients [8]. With a PR rate of $5.4-14.3 \%$, the objective response may be considered moderate. If, however, SD and PR are taken together as an acceptable goal of palliative treatment, the objective rate of disease stabilization (25.1-54.3\%) fits the results of the clinical benefit response evaluation much better.

Within an investigational new drug treatment program analyzing 3,023 pancreatic cancer patients treated with single-agent gemcitabine, a prospective evaluation of disease-related symptoms improvement yielded a cumulative rate of $18.4 \%$ after the fourth treatment cycle. In 982 evaluable patients, an overall RR of $12 \%$ (95\% confidence interval [CI], 10.0-14.0\%) was noted. For 2,380 patients with evaluable survival data, median survival was 4.8 months (95\% CI, 4.5-5.1 months) with a 1-year survival of $15 \%$ [4].

\section{High-Dose Gemcitabine and Prolonged Drug Application}

While a gemcitabine dose of $1,000-1,200 \mathrm{mg} / \mathrm{m}^{2}$ applied as a 30-min infusion has become a widely accepted standard for single-agent treatment, the optimal dose has not been defined so far. Fossella et al. [20] performed a phase I study in first-line non-small cell lung cancer (NSCLC) patients evaluating gemcitabine doses ranging from $1,000-2800 \mathrm{mg} / \mathrm{m}^{2}$. In this patient entity, a maximum tolerated dose of $2,200 \mathrm{mg} / \mathrm{m}^{2} /$ week for 3 weeks every 4 weeks was reported. 
Table 3. Gemcitabine plus cisplatin combination treatment in phase II studies

\begin{tabular}{|c|c|c|c|c|c|}
\hline Reference & $\mathrm{n} / \mathrm{eval}$ & Regimen & OR, $\%$ & $\mathrm{SD}, \%$ & $\begin{array}{l}\text { Survival } \\
\text { months }\end{array}$ \\
\hline 27 & $41 / 35$ & $\begin{array}{l}\text { Gemcitabine } 1,000 \mathrm{mg} / \mathrm{m}^{2}, \mathrm{~d} 1,8,15 \\
\text { Cisplatin } 50 \mathrm{mg} / \mathrm{m}^{2}, \mathrm{~d} 1,15, \mathrm{q} \text { d } 29\end{array}$ & 11.4 & 57.1 & 8.3 \\
\hline 29 & $52 / 32$ & $\begin{array}{l}\text { Gemcitabine } 1,000 \mathrm{mg} / \mathrm{m}^{2}, \text { wkly } \times 7 \\
\text { Cisplatin } 25 \mathrm{mg} / \mathrm{m}^{2}, \text { wk } 1-3 \text { and } 5-7 \text {, } \\
\text { then } 1 \text { wk rest, then d } 1,8,15 \mathrm{q} \mathrm{d} 29\end{array}$ & 31 & NA & NA \\
\hline 28 & $27 / 22$ & $\begin{array}{l}\text { Gemcitabine } 1,000 \mathrm{mg} / \mathrm{m}^{2}, \mathrm{~d} 1,8,15 \\
\text { Cisplatin } 50 \mathrm{mg} / \mathrm{m}^{2}, \mathrm{~d} 1,15, \mathrm{q} \mathrm{d} 29\end{array}$ & 36.4 & 27.3 & 7.4 \\
\hline 38 & $49 / 43$ & $\begin{array}{l}\text { Gemcitabine } 600 \mathrm{mg} / \mathrm{m}^{2}, \mathrm{~d} 1+8 \\
\text { Cisplatin } 40 \mathrm{mg} / \mathrm{m}^{2}, \mathrm{~d} 1 \\
\text { Epirubicin } 40 \mathrm{mg} / \mathrm{m}^{2}, \mathrm{~d} 1 \\
\text { 5-FU CI } 200 \mathrm{mg} / \mathrm{m}^{2}, \mathrm{~d} 1-28, \mathrm{q} 4 \text { weeks }\end{array}$ & 58 & 33 & $9.4+$ \\
\hline
\end{tabular}

$\mathrm{n} /$ eval $=$ Recruited/evaluable patients; 5 -FU $=5$-fluorouracil; OR $=$ overall remission; $\mathrm{SD}=$ stable disease $; \mathrm{NA}=$ not available $\mathrm{CI}=$ continuous infusion .
Pur et al. [21] undertook a phase II study in metastatic pancreatic cancer patients applying gemcitabine at the increased dose of $2,200 \mathrm{mg} / \mathrm{m}^{2}$ every 2 weeks. In 39 evaluable patients, a PR rate of $22.5 \%$, an SD rate of $40 \%$, and a median survival of 7.3 months were reported. Clinical benefit was observed in $37 \%(11 / 30)$ of patients. These data would argue for a dose increase of gemcitabine, because comparable treatment results have not been achieved with standard doses in the range of $800-1,000$ $\mathrm{mg} / \mathrm{m}^{2}$ (table 2).

However, these data need to be discussed in the context of the results of the following randomized phase II trial of dose-intense gemcitabine by Tempero et al. [22]. In the standard infusion arm (A), gemcitabine was administered to 37 patients with metastatic disease at a dose of $2,200 \mathrm{mg} / \mathrm{m}^{2}$ (30-min. i.v. infusion) weekly times three every 4 weeks. While dose intensity was greater in this trial, the RR was only $2.7 \%$ with a median survival of 4.7 months and a 1-year survival of $0 \%$. These results are not only in striking contrast to the results published by Pur et al., they also do not fit into the context of the data so far reported for single-agent gemcitabine as shown in table 2 . The comparator arm (B) of this trial investigated the efficacy of a fixed gemcitabine dose rate of $10 \mathrm{mg} / \mathrm{m}^{2}$ per minute. This dose rate was chosen because previous studies had demonstrated saturation of the activating enzyme deoxycytidine kinase. Thirty patients received $1,500 \mathrm{mg} /$ $\mathrm{m}^{2}$ as a $150-$ min infusion. This schedule resulted in an RR of $16.6 \%$, a median survival of 6.1 months, and a 1 -year survival of $23 \%$. The promising activity achieved with the fixed dose rate in arm B seems to support the underlying pharmacologic mechanism; however, the need for confirmatory phase III trials is clearly needed, and no definitive conclusions may be drawn at the present time.

\section{Combination Therapy with Gemcitabine and Cisplatin}

Preclinical studies have demonstrated that gemcitabine acts as an effective inhibitor of DNA repair [23]. In fact, synergistic cytotoxicity was observed under conditions where gemcitabine inhibited adequate repair of DNA damage caused by cisplatin or radiation [24, 25]. While cisplatin alone has some activity in pancreatic cancer and induced a remission rate of $21 \%$ in one phase II study, median survival was not extended beyond 4.0 months [26]

Therefore, a phase II study was initiated to determine the impact of gemcitabine/cisplatin combination treatment on clinical efficacy and quality of life in pancreatic cancer patients [27]. A total of 41 patients received gemcitabine at a dose of $1,000 \mathrm{mg} / \mathrm{m}^{2}$ (days 1,8 , and 15) and cisplatin at a dose of $50 \mathrm{mg} / \mathrm{m}^{2}$ (days 1 and 15), every 29 days. In 35 evaluable patients, an overall RR of $11.5 \%$ (95\% CI, 3.2-26.7\%) was observed that was accompanied by disease stabilization ( $\geq 3$ months) in $57.1 \%$ of patients. In other words, this regimen achieved at least a transient stabilization of disease (CR + PR + SD) in 69\% of patients. Median survival was 8.3 months and appears superior to the 3-5 months expected in patients receiving best supportive care alone. After 1 year, $28 \%$ of patients 
Table 4. Survival of pancreatic cancer patients in relation to first-line treatment

\begin{tabular}{|c|c|c|c|c|}
\hline Reference & $\begin{array}{l}15 \\
5 \text {-FU/Cisplatin } \\
\text { Phase III }\end{array}$ & $\begin{array}{l}8 \\
\text { Gemcitabine } \\
\text { Phase III }\end{array}$ & $\begin{array}{l}7 \\
\text { Gemcitabine/5-FU } \\
\text { Phase II }\end{array}$ & $\begin{array}{l}27 \\
\text { Gemcitabine/Cisplatin } \\
\text { Phase II }\end{array}$ \\
\hline $\mathrm{n} / \mathrm{eval}$ & $104 / 94$ & $63 / 56$ & $54 / 54$ & $41 / 35$ \\
\hline Regimen & $\begin{array}{l}5 \text {-FU } 1,000 \mathrm{mg} / \mathrm{m}^{2} \\
\text { CI } 24 \mathrm{~h}, \mathrm{~d} 1-5, \mathrm{q} \mathrm{d} 29 \\
\text { Cisplatin } 100 \mathrm{mg} / \mathrm{m}^{2}, \mathrm{~d} 1\end{array}$ & $\begin{array}{l}\text { Gemcitabine } 1,000 \mathrm{mg} / \mathrm{m}^{2} \\
\text { weekly } \times 7,1 \text { week rest } \\
\text { then d } 1,8,15, \text { q d } 29\end{array}$ & $\begin{array}{l}\text { Gemcitabine } 1,000 \mathrm{mg} / \mathrm{m}^{2} \\
5 \text {-FU } 600 \mathrm{mg} / \mathrm{m}^{2} \text { bolus } \\
\mathrm{d} 1,8,15, \mathrm{q} \mathrm{d} 29\end{array}$ & $\begin{array}{l}\text { Gemcitabine } 1,000 \mathrm{mg} / \mathrm{m}^{2} \\
\mathrm{~d} 1,8,15, \mathrm{q} \mathrm{d} 29 \\
\text { Cisplatin } 50 \mathrm{mg} / \mathrm{m}^{2}, \mathrm{~d} 1,15\end{array}$ \\
\hline Median survival, months & NA & 5.7 & 7.0 & 8.3 \\
\hline 6-month survival, $\%$ & 38 & 46 & 61 & 69 \\
\hline 9-month survival, $\%$ & NA & 24 & 35 & 43 \\
\hline 12-month survival, $\%$ & 17 & 18 & 22 & 28 \\
\hline
\end{tabular}

$\mathrm{n} / \mathrm{eval}=$ Recruited/evaluable patients; $\mathrm{CI}=$ continuous infusion; 5-FU = 5-fluorouracil; NA = not available .

survived. Philip et al [28] used the identical regimen and achieved a median survival of 7.4 months (table 3 ). In a phase III randomized trial, Burris et al. [8] reported a 1year survival of $2 \%$ in patients receiving 5 -FU alone, and $18 \%$ with single-agent gemcitabine. In another randomized trial [15], 5-FU single-agent treatment induced a 1year survival of $9 \%$, while the combined application of 5 FU and cisplatin yielded a survival rate of 17\% (table 4).

Combined treatment with gemcitabine and cisplatin appears to override the notorious chemoresistance of pancreatic cancer, although phase III trials are clearly necessary to determine if this regimen represents a marked progress of chemotherapeutic efficacy in this rather dismal patient entity. It remains unclear, however, the extent to which patient selection contributed to treatment outcome and the extent to which greater efficacy is achieved at the expense of quality of life. To answer these questions, randomized studies were initiated comparing single-agent gemcitabine to gemcitabine/cisplatin. In one such study by Colucci et al. [29], preliminary results have already been published. Thirty patients receiving a weekly application of gemcitabine $1,000 \mathrm{mg} / \mathrm{m}^{2}$ achieved a response rate of $10 \%$, while the other 32 patients treated with the same regimen of gemcitabine and cisplatin at a dose of $25 \mathrm{mg} / \mathrm{m}^{2}$ reached a response rate of $42 \%$. Clinical benefit responses were 45 and $38 \%$, respectively. Although promising, the significance of these data is too premature to assess; moreover, survival data are not yet available.

A German multicenter study comparing gemcitabine $1,000 \mathrm{mg} / \mathrm{m}^{2}$ (day 1,8 , and 15 ) to cisplatin $50 \mathrm{mg} / \mathrm{m}^{2}$ plus gemcitabine $1,000 \mathrm{mg} / \mathrm{m}^{2}$ (days 1 and 15 ), every 28 days, is currently ongoing.

\section{Combination Therapy with Gemcitabine and 5-Fluorouracil}

5-Fluorouracil (5-FU) has been thoroughly investigated as a combination partner for gemcitabine, and a number of preclinical studies demonstrate synergistic interactions between the two antimetabolites [27]. While gemcitabine increases 5-FU activity by depletion of cellular deoxyuridine monophosphate (dUMP) pools and inhibition of thymidylate synthase, 5-FU prevents inactivation of gemcitabine monophosphate by deamination.

Five phase I-II studies [7, 30-33] using gemcitabine in combination with standard doses of 5-FU yielded response rates $(\mathrm{CR}+\mathrm{PR})$ of $3.7-43 \%$ with a median survival of 7.0-13 months (table 5). One-year survival was reported in one study [7] and amounted to $22 \%$. Among studies, however, there was not only a great variability of evaluable patient numbers, but also considerable variation among 5-FU applications, which included bolus, 3hour, and continuous infusion regimens. It may, therefore, not be surprising to find marked differences among these studies in treatment response and survival.

A further four studies [34-37] evaluated high-dose 5FU in various combinations with gemcitabine (table 6). They achieved response rates of $9.5-19 \%$, and a median survival of 5.5-8.0 months. A comparison of survival achieved by gemcitabine in combination with standarddose (7-13 months) or high-dose 5-FU (5.5-8 months) still does not provide evidence for a greater activity of either regimen (table 4). Clinical benefit response across all nine studies ranged from 45 to $57 \%$. 
Table 5. Gemcitabine plus standard-dose 5-FU

\begin{tabular}{|c|c|c|c|c|c|c|c|}
\hline Reference & Phase & n/eval & Regimen & OR, $\%$ & $\mathrm{SD}, \%$ & $\begin{array}{l}\text { Clinical } \\
\text { benefit, } \%\end{array}$ & $\begin{array}{l}\text { Survival } \\
\text { months }\end{array}$ \\
\hline 7 & II & 54 & $\begin{array}{l}\text { 5-FU } 600 \mathrm{mg} / \mathrm{m}^{2}, \text { bolus } \\
\text { Gemcitabine } 1,000 \mathrm{mg} / \mathrm{m}^{2} \\
\text { d } 1,8,15, \text { q d } 29\end{array}$ & 3.7 & 63 & 51 & 7.0 \\
\hline 32 & II & $24 / 22$ & $\begin{array}{l}\text { 5-FU } 600 \mathrm{mg} / \mathrm{m}^{2} \text {, bolus } \\
\text { Gemcitabine } 1,000 \mathrm{mg} / \mathrm{m}^{2} \\
\text { d } 1,8,15, \text { q d } 29\end{array}$ & 12.5 & 22.4 & $\left(69.9^{*}\right)$ & 7.5 \\
\hline 30 & II & 14 & $\begin{array}{l}5 \text {-FU } 500 \mathrm{mg} / \mathrm{m}^{2}, 3 \mathrm{~h} \\
\text { Gemcitabine } 1,000 \mathrm{mg} / \mathrm{m}^{2} \\
\text { d } 1,8,15, \text { q d } 29\end{array}$ & 42.8 & NA & 50 & 13.0 \\
\hline 31 & I-II & 26 & $\begin{array}{l}\text { 5-FU } 200 \mathrm{mg} / \mathrm{m}^{2}, \mathrm{CI}, \mathrm{d} 1-29 \\
\text { Gemcitabine } 700-1,000 \mathrm{mg} / \mathrm{m}^{2 * *} \\
\text { d } 1,8,15, \text { q d } 29\end{array}$ & 19.2 & 42 & 45 & 10.3 \\
\hline 33 & II & 15 & $\begin{array}{l}\text { 5-FU } 200 \mathrm{mg} / \mathrm{m}^{2}, \mathrm{CI}, \mathrm{d} 1-21 \\
\text { Gemcitabine } 600 \mathrm{mg} / \mathrm{m}^{2} \\
\text { d } 1,8,15, \text { q d } 29\end{array}$ & 13 & 40 & NA & 8.0 \\
\hline
\end{tabular}

* Reported as PS improvement.

** Recommended gemcitabine dose $=900 \mathrm{mg} / \mathrm{m}^{2}$.

$\mathrm{n} /$ eval $=$ recruited/evaluable patients; 5-FU $=5$-fluorouracil; $\mathrm{CI}=$ continuous infusion; $\mathrm{OR}=$ overall remission; $\mathrm{SD}=$ stable disease $; \mathrm{NA}=$ not available .

Table 6. Gemcitabine plus high-dose 5-FU

\begin{tabular}{|c|c|c|c|c|c|c|c|}
\hline Reference & Phase & n/eval & Regimen & OR, $\%$ & $\mathrm{SD}, \%$ & $\begin{array}{l}\text { Clinical } \\
\text { benefit, \% }\end{array}$ & $\begin{array}{l}\text { Survival } \\
\text { months }\end{array}$ \\
\hline 37 & I-II & $23 / 21$ & $\begin{array}{l}\text { 5-FU } 3,000 \mathrm{mg} / \mathrm{m}^{2}, \text { CI } 48 \mathrm{~h} \text {, weekly } \\
\text { Gemcitabine } 800-1,400 \mathrm{mg} / \mathrm{m}^{2} \\
\text { weekly } \times 3 \text {, q d } 29\end{array}$ & 19.0 & 33 & 57 & 5.5 \\
\hline 35 & II & $63 / 48$ & $\begin{array}{l}\text { FA } 400 \mathrm{mg} / \mathrm{m}^{2}, 2 \mathrm{~h}, \mathrm{~d} 1 \\
5 \text {-FU } 400 \mathrm{mg} / \mathrm{m}^{2} \text { bolus, d } 1 \\
5 \text {-FU } 2,000-3,000 \mathrm{mg} / \mathrm{m}^{2}, \mathrm{CI} 48 \mathrm{~h}, \mathrm{~d} 1-2 \\
\text { Gemcitabine } 1,000-1,500 \mathrm{mg} / \mathrm{m}^{2}, \mathrm{~d} 3 \\
\text { q } 2 \text { weeks }\end{array}$ & 19.1 & NA & 50 & 8.0 \\
\hline 34 & I-II & $22 / 21$ & $\begin{array}{l}\text { Gemcitabine } 1,000 \mathrm{mg} / \mathrm{m}^{2}, \mathrm{~d} 1 \\
\text { FA } 250 \mathrm{mg} / \mathrm{m}^{2}, 2 \mathrm{~h}, \mathrm{~d} 1 \\
5-F U 1,400-2,600 \mathrm{mg} / \mathrm{m}^{2}, \text { CI } 24 \mathrm{~h}, \mathrm{~d} 1 \\
\text { weekly } \times 3, \mathrm{q} \text { d } 29\end{array}$ & 9.5 & 52 & 56 & NA \\
\hline 36 & II & 15 & $\begin{array}{l}\text { Gemcitabine } 1,000 \mathrm{mg} / \mathrm{m}^{2} \\
5 \text {-FU } 2,000 \mathrm{mg} / \mathrm{m}^{2}, \text { CI } 24 \mathrm{~h} \\
\text { weekly } \times 3, \text { q d } 29\end{array}$ & 14 & 50 & NA & $\begin{array}{l}1 \text {-year } \\
\text { survival } \\
=36 \%\end{array}$ \\
\hline
\end{tabular}

$\mathrm{n} /$ eval = Recruited/evaluable patients; FA = folinic acid; 5-FU = 5-fluorouracil; $\mathrm{CI}$ = continuous infusion; $\mathrm{OR}=$ overall remission; $\mathrm{NA}=$ not available. 


\section{Gemcitabine-Based Four-Drug Regimens}

Reni et al. [38] performed a four-drug study including gemcitabine $\left(600 \mathrm{mg} / \mathrm{m}^{2}\right.$ days 1 and 8$)$, cisplatin $(40 \mathrm{mg} /$ $\mathrm{m}^{2}$ day 1$)$, epirubicin $\left(40 \mathrm{mg} / \mathrm{m}^{2}\right.$ day 1$)$ and continuous infusion 5-FU (200 mg/m² days 1-28). In 43 evaluable stage IV patients, a response rate of $58 \%$, and a median survival of $9.4+$ months (1-year survival $=40+\%)$ were reported (table 3 ). Hematologic toxicity was reported with WHO grade 3-4 neutropenia in 51\% and thrombocytopenia in $28 \%$ of patients. The results of this four-drug regimen are highly encouraging and may lead the way to intensive multi-drug regimens applicable in selected patients.

An additional trial [39] analyzed combined treatment with leucovorin $\left(400 \mathrm{mg} / \mathrm{m}^{2}\right.$, day 1$), 5-F U$ bolus $(400 \mathrm{mg} /$ $\mathrm{m}^{2}$, day 1), 5-FU 48-hour continuous infusion $(2,000-$ $2,400 \mathrm{mg} / \mathrm{m}^{2}$, days 1 and 2), followed by gemcitabine $\left(800 \mathrm{mg} / \mathrm{m}^{2}\right.$, day 3$)$ and oxaliplatin $\left(85 \mathrm{mg} / \mathrm{m}^{2}\right.$, day 3$)$. In 23 patients with advanced pancreatic cancer $(n=14)$ and cancer of unknown primary $(n=9)$, a response rate of $35 \%$ was observed. In the group of pancreatic cancer patients, 2 CRs, 2 PRs, a median progression-free survival of 8 months, and a median survival of 9 months were reported.

\section{Gemcitabine Combined with Irinotecan or Docetaxel: Preliminary Data}

Results of preliminary studies evaluating the clinical impact of irinotecan (CPT-11) or docetaxel in combination with gemcitabine in patients with pancreatic cancer have recently been reported.

Two phase II, multicenter studies of irinotecan, a topoisomerase inhibitor, plus gemcitabine in chemonaive patients with locally advanced and metastatic pancreatic cancer have demonstrated response rates of 20\% (45 evaluable patients) and 15\% (20 evaluable patients), respectively [40, 41]. Both studies used the same 3-week schedule, but the former administered irinotecan $100 \mathrm{mg} / \mathrm{m}^{2}$ and gemcitabine $1,000 \mathrm{mg} / \mathrm{m}^{2}$ on both days 1 and 8 , while the latter administered a higher dose of irinotecan, $300 \mathrm{mg} / \mathrm{m}^{2}$, on day 8 only with gemcitabine $900 \mathrm{mg} / \mathrm{m}^{2}$ on days 1 and 8 . Both regimens were considered well tolerated and relatively active with possibilities for further phase III study.

Based on promising phase II data [40], Rocha Lima and colleagues have initiated a randomized multicenter phase III trial (MUSC 8982) comparing the combination of irinotecan $100 \mathrm{mg} / \mathrm{m}^{2}$ (days 1 and 8 ), plus gemcitabine $1,000 \mathrm{mg} / \mathrm{m}^{2}$ (days 1 and 8), every 21 days; with gemcitabine $1,000 \mathrm{mg} / \mathrm{m}^{2}$ (weekly $\times 7$ for the 1 st cycle, then days 1,8 , and 15 ), every 28 days. The primary endpoint is survival, with secondary measures of objective response, CA19-9, time to treatment failure, safety, PS, weight loss, albumin, and quality of life. Target accrual is 350 patients (175 per study arm) at a rate of 20 per month; follow-up will be 12 months. The investigators have accrued 60 patients, and seek a 2-month difference in median survival (Rocha Lima, personal communication).

In a phase I study, maximum tolerated dose study of escalating dose levels of docetaxel $\left(25-40 \mathrm{mg} / \mathrm{m}^{2}\right)$ and gemcitabine $\left(800\right.$ or $1,000 \mathrm{mg} / \mathrm{m}^{2}$ ) in 25 chemonaive patients with locally advanced or metastatic pancreatic carcinoma, the recommended dose level was established at gemcitabine $1,000 \mathrm{mg} / \mathrm{m}^{2}$ plus docetaxel $35 \mathrm{mg} / \mathrm{m}^{2}$ administered weekly at 3-week intervals [42]. Dose-limiting toxicities included WHO grades 3 and 4 gastrointestinal toxicity and leukopenia. Preliminary efficacy results in the phase II ongoing study are encouraging with a $23 \%$ objective response rate and disease stabilization rate of $69 \%$ in 13 patients included thus far.

A phase I/II study in pancreatic cancer evaluated two regimens of gemcitabine and docetaxel: gemcitabine $800 \mathrm{mg} / \mathrm{m}^{2}$ on days 1,8 and 15 and docetaxel $75 \mathrm{mg} / \mathrm{m}^{2}$ on day 1 of a 28-day schedule (Group A, $\mathrm{n}=18$ ), and gemcitabine $1,000 \mathrm{mg} / \mathrm{m}^{2}$ and docetaxel $40 \mathrm{mg} / \mathrm{m}^{2}$ on days 1 and 8 on a 21-day schedule (Group B, $n=11$ ) [43]. The former schedule (A) was changed due to excessive hematologic toxicity requiring a dose reduction in 13 patients. (Schedule B, days 1 and 8 every 21 days, is the recommended regimen [Jacobs, pers. commun.]) Of the 25 patients evaluable for response, 7 (28\%) achieved a PR and $10(40 \%)$ either a minor response or stable disease. Sites of response were pancreas, peritoneum, lung, skin, and liver. Median time to progression was 5.25 months. The regimen in Group B was better tolerated with only two patients with hematologic toxicity (grade 2) versus 13 patients (grades 2/3) in Group A. The authors concluded that the response and survival data were encouraging given the poor prognosis for this cancer and the few palliative choices available.

In another phase II study in which all patients had metastatic disease, gemcitabine $600 \mathrm{mg} / \mathrm{m}^{2}$ on days 1,8 , and 15 plus docetaxel $60 \mathrm{mg} / \mathrm{m}^{2}$ on day 1 over 28 -day cycles yielded an overall response rate of $8 \%$ (2/24 patients) including one CR [44]. However, an additional 4 of 7 patients with SD after four cycles had a greater than $75 \%$ reduction in CA 19-9 titer. 
Table 7. Ongoing gemcitabine studies in pancreatic cancer

\begin{tabular}{llll}
\hline Study & Design & Chemotherapy & Investigator \\
\hline MUSC 8982 & $\begin{array}{l}\text { Randomized } \\
\text { Phase III }\end{array}$ & Gem + CPT-11 vs. gem & Rocha Lima \\
CALGB 89805 & $\begin{array}{l}\text { Phase II } \\
\text { Randomized } \\
\text { Phase II }\end{array}$ & $\begin{array}{l}\text { Gem + radiation } \\
\text { Gem + cis; gem + doc; } \\
\text { gem + CPT-11; }\end{array}$ & $\begin{array}{l}\text { Blackstock/Tempero } \\
\text { Kulke, Tempero }\end{array}$ \\
& high-dose single-agent gem & \\
ECOG E-1298 & Phase II & Gem + doc & Shepard \\
NCCTG 964352 & Phase I & Gem + cis + radiation & Not available
\end{tabular}

CALGB = Cancer and Leukemia Group B; cis = cisplatin; CPT-11 = irinotecan; doc = docetaxel; ECOG = Eastern Cooperative Oncology Group; gem = gemcitabine; MUSC = Medical University of South Carolina; NCCTG = North Central Cancer Treatment Group.

\section{Gemcitabine and Matrix Metalloprotease Inhibitors}

Matrix metalloproteases (MMPs) represent a group of zinc-dependent enzymes involved in remodelling and turnover of extracellular matrix proteins, play a role in wound healing, and are involved in the pathogenesis of arthritis. Because MMPs are related to the tumor's ability to metastasize and the in the process of angiogenesis, high expression of MMPs is associated with cancer malignancy. Treatment with MMP inhibitors (MMPIs) alone or in combination with cytotoxic therapy is a novel approach in the control of tumor progression and, thus, the management of malignancies. Based on promising preclinical studies, synthetic MMPIs, such as marimastat, BAY 129566, CGS-27023A, prinomastat (AG-3340), BMS275291, and metastat (COL-3), have been developed and included in clinical trials [45]. These drugs are involved at all stages of clinical drug development. The MMPIs have been evaluated as single agents, as well as in combination with other chemotherapeutic agents with the objective of reducing the size and number of metastatic lesions.

To determine whether MMPIs are capable of potentiating the effects of chemotherapy, various phase I trials were initiated to examine the safety of concomitant treatment. In a phase I study of the combination of gemcitabine and marimastat as first-line therapy [46], sequential marimastat doses of 5, 10, 15, and $20 \mathrm{mg}$ BID were evaluated in 31 patients. Gemcitabine was administered at a dose of $1,000 \mathrm{mg} / \mathrm{m}^{2}$ weekly for 3 of 4 weeks. Six patients experienced significant musculoskeletal toxicity related to marimastat therapy. Other toxicities included grade 4 elevated bilirubin, myelopsuppression, abnormal liver function tests, and back pain; the remaining toxicities were mild. Of the 11 evaluable patients, response was detected in 2 patients and stable disease in 6 patients. Sustained declines in CA19-9 were recorded in 9 patients. The authors concluded that marimastat, when combined with gemcitabine, did not appear to increase the incidence or severity of chemotherapy-related adverse events.

A number of phase III clinical trials comparing gemcitabine to MMPIs are ongoing, but only one, conducted by Rosemurgy et al., has been reported thus far [47, 48]. This study compared gemcitabine to marimastat as first-line therapy in 414 patients with unresectable pancreatic cancer. Patients were randomized to marimastat $(5,10$, or $25 \mathrm{mg}$ BID) or gemcitabine $1,000 \mathrm{mg} / \mathrm{m}^{2}$ weekly for 7 of 8 weeks and then weekly for 3 of 4 weeks until the occurrence of disease progression or toxicity. With the study designed to detect a $16 \%$ or greater reduction in mortality, no statistically significant differences between gemcitabine and the three doses of marimastat were found in terms of the primary endpoint of overall survival. Safety data revealed no marked differences between the treatment groups other than the expected side effects of musculoskeletal toxicity with marimastat and the hematologic toxicity with gemcitabine.

\section{Future Directions}

A number of ongoing studies in advanced metastatic and/or locally advanced pancreatic cancer utilizing gemcitabine in combination with other agents is summarized in table 7. 


\section{Conclusions}

Gemcitabine has been successfully introduced as a well-tolerated agent in the treatment of pancreatic cancer, and is presently recommended as the standard of care for first-line treatment of pancreatic cancer. The activity observed with the combination of gemcitabine with cisplatin or 5-FU appears promising (table 6), although its superiority to single-agent treatment regarding response rates and survival needs to be confirmed in randomized, phase III trials, which are ongoing or completed but not yet published. Randomized trials comparing single-agent gemcitabine to combination treatment are presently ongoing. Gemcitabine-based four-drug regimens promise a further increase of efficacy, but confirmatory trials are needed. Preliminary data from the recent coupling of gemcitabine with irinotecan, docetaxel, or MMPIs offer another encouraging alternative for pancreatic cancer.

\section{References}

1 Parker SL, Tong T, Bold S, Wingo PA: Cancer statistics. CA Cancer Clin 1997;47:5-27.

2 Wanebo HJ, Vezeridis MP: Pancreatic Carcinoma in perspective: A continuing challenge. Cancer 1996;78:580-591.

3 Moore M: Activity of gemcitabine in patients with advanced pancreatic carcinoma. Cancer 1996; 78:633-638.

4 Storniolo AM, Enas MH, Brown CA, Voi M, Rothenberg ML, Schilsky R: An investigational new drug treatment program for patients with gemcitabine. Cancer 1999;85:1261-1268.

5 Rothenberg ML, Abbruzzese JL, Moore M, Portenoy RK, Robertson JM, Wanebo HJ: A rationale for expanding the endpoints for clinical trials in advanced pancreatic carcinoma. Cancer 1996;78:627-632.

6 Ahlgren JD: Chemotherapy for pancreatic carcinoma. Cancer 1996;78:654-63.

7 Cascinu S, Silva RR, Barni S, Labianca R, Frontini L, Piazza E, Pancera G, Giordani P, Giuliodori L, Pessi MA, Fusco V, Luporini G, Cellerino R, Catalano G: A combination of gemcitabine and 5-fluorouracil in advanced pancreatic cancer, a report from the Italian Group for the Study of Digestive Tract Cancer (GISCAD). Br J Cancer 1999;80:1595-1598.

8 Burris HA, Moore MJ, Andersen J, Green MR, Rothenberg ML, Modiano MR, Cripps C, Portenoy RK, Storniolo AM, Tarassoff P, Nelson R, Dorr FA, Stephens CD, von Hoff DD: Improvements in survival and clinical benefit with gemcitabine as first-line therapy for patients with advanced pancreas cancer: A randomized trial. J Clin Oncol 1997;15:24032413.

9 Rothenberg ML, Moore M, Cripps MC, Andersen JS, Portenoy RK, Burris III HA, Green MR, Tarassoff PG, Brown TD, Casper ES, Storniolo A-M, von Hoff DD: A phase II trial of gemcitabine in patients with 5-FU-refractory pancreas cancer. Ann Oncol 1996;7:347353 .

10 Gattani AM, Mandeli J, Bruckner HW: Tumor markers in patients with pancreatic carcinoma. Cancer 1996;78:57-62.
11 Glenn J, Steinberg WM, Kurtzman SH, Steinberg SM, Sindelar WF: Evaluation of the utility of a radioimmunoassay for serum CA 19-9 levels in patients before and after treatment of carcinoma of the pancreas. J Clin Oncol 1988;6: 462-468.

12 Lundin J, Roberts PJ, Kuusela P, Haglund C: The prognostic value of preoperative serum levels of CA 19-9 and CEA in patients with pancreatic cancer. Br J Cancer 1994;69:515519 .

13 Willett CG, Daly WJ, Warshaw AL: CA 19-9 is an index of response to neoadjuvant chemoradiation therapy in pancreatic cancer. Am J Surg 1996;172: 350-352.

14 Heinemann V, Schermuly MM, Stieber P, Schulz L, Jüngst D, Wilkowski R, Schalhorn A CA 19-9: A predictor of response in pancreatic cancer treated with gemcitabine and cisplatin. Anticancer Res 1999;19:1-3.

15 Rougier P, Ducreux M, Douillard JY, Seitz JF, Bugat R, Bosset JF, Merouche Y, Raoul JL, Ychou M, Adenis A, Cvitkovic Bertheau F, Luboinski M, Pignon JP: Efficacy of 5-FU + cisplatin (FUP) compared to bolus 5-FU (FU) in advanced pancreatic carcinoma (APC): A randomized trial from the French Anticancer Centers Digestive Group (FNLCCDG). Proc Am Soc Clin Oncol 1999; 18:(abstract 1050).

16 Cullinan S, Moertel CG, Wieand HS, Schutt AJ, Krook JE, Foley JF, Norris BN, Kardinal CG, Tschetter LK, Barlow JF: A phase III trial on the therapy of advanced pancreatic carcinoma. Cancer 1990;65:2207-2212.

17 Heinemann V, Hertel LW, Grindey GB, Plunkett W: Comparison of the cellular pharmacokinetics and toxicity of $2^{\prime}, 2^{\prime}$-difluoro- $2^{\prime}$-deoxycytidine and 1- $\beta$-D-arabinofuranosylcytosine. Cancer Res 1988;48:4024-4031.

18 Carmichael J, Fink U, Russell RCG, Spittle M F, Harris A L, Spiessl G, Blatter J: Phase II study of gemcitabine in patients with advanced pancreatic cancer. Br J Cancer 1995;73:101105.

19 Casper ES, Green MR, Kelsen DP, Heelan RT, Brown TD, Flombaum CD, Trochanowski B, Tarassoff PG: Phase II trial of gemcitabine $\left(2^{\prime}, 2^{\prime}\right.$-difluorodeoxycytidine) in patients with adenocarcinoma of the pancreas. Invest New Drugs 1994;12:29-34.
20 Fossella FV, Lippman SM, Shin DM, Tarassoff $\mathrm{P}$, Calayag-Jung M, Perez-Soler R, Lee JS, Murphy WK, Glisson B, Rivera E, Hong WK: Maximum-tolerated dose defined for singleagent gemcitabine: A phase I dose-escalation study in chemotherapy-naive patients with advanced non-small-cell lung cancer. J Clin Oncol 1997:15:310-316.

21 Pur HU, Kornek GV, Raderer M, Fiebiger W, Zickero G, Pidlich J, Greul R, Schneeweiss B, Depisch D, Scheithauer W: Phase II trial of high-dose gemcitabine in patients with metastatic pancreatic adenocarcinoma. Onkologie 1999;22(suppl 1):81.

22 Tempero M, Plunkett W, Ruiz van Harperen V, Hainsworth J, Hochster H, Lenzi R, Abbruzzese J: Randomised phase II trial of dose intense gemcitabine by standard infusion vs. fixed dose rate in metastatic pancreatic adenocarcinoma. Proc Am Soc Clin Oncol 1999;18: 273a (abstract 1048).

23 Plunkett W, Huang P, Gandhi V: Preclinical characteristics of gemcitabine. Anticancer Drugs 1995;6:7-13.

24 Bergman AM, Ruiz van Haperen VWT, Veerman G, Kuiper CM, Peters GJ: Synergistic interaction between cisplatin and gemcitabine in ovarian and colon cancer cell lines. Purine and Pyrimidine Metabolism in Man 1995; 7 : 139-143.

25 Shewach DS, Lawrence TS: Radiosensitization of human tumor cells by gemcitabine in vitro. Semin Oncol 1995;22(suppl 11):68-71.

26 Wils JA, Kok T, Wagener D JTh, Selleslags J, Duez N: Activity of cisplatin in adenocarcinoma of the pancreas. Eur J Cancer 1993; 29A:203-204.

27 Heinemann V, Wilke H, Possinger K, Mergenthaler H-G, Clemens M, König HJ, Illiger HJ, Ohnmacht U, Arning M, Schalhorn A, Fink U: Gemcitabine and cisplatin in the treatment of advanced and metastatic pancreatic cancer. Final results of a phase II study. Proc Am Soc Clin Oncol 1999;18:274a (abstract 1052).

28 Philip PA, Zalupski M, Vaitkevicius VK, Arlauskas P, Shields A: Phase II study of gemcitabine and cisplatin in advanced or metastatic pancreatic cancer. Proc Am Soc Clin Oncol 1999; 18:274a (abstract 1053). 
29 Colucci G, Riccardi F, Giuliani F, Lopez M, Gebbia V, Uomo M, Biglietto Mcigolari S, Borsellino N, Paoletti G, Maiello E, Gebbia N: Randomized trial of gemcitabine (GEM) alone or with cisplatin (CDDP) in the treatment of advanced pancreatic cancer (APC): A phase II multicenter study of the Southern Italy Oncology Group. Proc Am Soc Clin Oncol 1999;18: 250a (abstract 961)

30 De Gusmao CBRA, Murad AM, ScalabriniNeto AM: Phase II trial of the use of gemcitabine and 5-fluorouracil in the treatment of advanced pancreatic and biliary tract adenocarcinoma. Proc Am Soc Clin Oncol 1998;17: abstract 1116 .

31 Hidalgo M, Castellano D, Paz-Ares L, Gravalos C, Diaz-Puente M, Hitt R, Alonso S, Cortes-Funes H: Phase I-II study of gemcitabine and fluorouracil as a continuous infusion in patients with pancreatic cancer. J Clin Oncol 1999; 17:585-592.

32 Pastorelli D, Peddrazoli S, Sperti C, Vicario G, Scelzi E, Santarossa S, Sgarbossa G, Fosser V, Manente P: Phase II trial with gemcitabine $(\mathrm{GEM})+$ 5-fluorouracil (5-FU) in advanced pancreatic cancer (APC). Proc Am Soc Clin Oncol 2000;19:abstract 1110.

33 Schulman KL, Kindler HL, Lad TE, Reilly K, Mani S, Vokes EE: Phase II study of gemcitabine $(\mathrm{G})$ and continuous intravenous infusion (CIV) 5-fluorouracil (5-FU) in advanced pancreatic cancer (PC): A University of Chicago phase II consortium study. Proc Am Soc Clin Oncol 2000;19:abstract 1126

34 Lencioni M, Falcone A, Masi G, Fioretto L, Meucci I, Di Marsico R, Pfanner E, Galli C, Bonifazi V, Mazzocchi B, Tognarini L, Conte P: Phase I-II study of gemcitabine in combination with 24 hours continuous infusion (CI) of 5-fluorouracil 5-FU) and L-leucovorin (LV) in patients (pts) with advanced pancreatic carcinoma. Proc Am Soc Clin Oncol 2000;19:abstract 1235 .
35 Louvet C, Hammel P, Andre T, Vanica R, Landi B, Balosso J, Cattan S, Fonck M, Flesch M, Colin P, Gruson T, de Gramont A: Multicenter phase II study in advanced pancreatic adenocarcinoma patients treated with a combination of leucovorin, 5-FU bolus and infusion, and gemcitabine (FOLFUGEM regimen). Proc Am Soc Clin Oncol 1999;18:abstract 1054.

36 Riedel C, Wein A, Wehler M, Lampert S, Fischer B, Hohenberger W, Hahn E, Schneider T: High-dose 5-fluorouracil (FU) 24-hour-infusion with gemcitabine (GEM): Tolerable and efficient in palliative outpatient treatment of pancreatic cancer. Proc Am Soc Clin Oncol 2000; 19:abstract 1248.

37 Rodriguez-Lescure A, Carrato A, Massuti B, Garcia-Gomez J, Herrero J, Gallego J, DiazFernandez N, Gonzalvez ML: Phase II study of gemcitabine (GEM) and weekly 48-hour continuous infusion (CI) high dose 5-fluorouracil (5-FU) in advanced exocrine pancreatic cancer (APC). Proc Am Soc Clin Oncol 1999;18: abstract 1145 .

38 Reni M, Passoni P, Villa E: Definitive results of a phase II trial PEF-G (cisplatin, epirubicin, 5-fluorouracil continuous infusion, gemcitabine) in stage IV pancreatic adenocarcinoma. Proc Am Soc Clin Oncol 2000;19:abstract 1019.

39 Mousseau M, Rebischung C, Garnier C, Chirpaz E, Provencal J, Papillon E, Balosso J, Charlety D, Lemoigne A, Pasquier D, Schaerer R, Esterni J: Phase I/II study in advanced pancreatic adenocarcinoma (APA) and carcinoma of unknown primary (CUP): A combination of leucovorin (LV), 5-FU bolus and infusion, gemcitabine (GEM), and oxaliplatin (L.OHP) (FOLFU GEMOX Regimen). Proc Am Soc Clin Oncol 2000;19:abstract 913.

40 Rocha Lima C, Savarese D, Bruchner H, Dudek A, Echardt J, Hainsworth J, Lester E, Compton L, Locker P, Elfring G, Miller L, Green M: Multicenter phase II trial of first-line irinotecan and gemcitabine (Irinogem) in patients with locally advanced or metastatic pancreatic cancer (PC). Proc Am Soc Clin Oncol 2000;19:263a (abstract 1023).
41 Stathopoulos G, Rigatos G, Dimopoulos M, Kouroussis C, Panopoulos C, Giannakakis T, Tzanninis D, Georgoulias V: Front-line treatment of pancreatic carcinoma with gemcitabine (GMB) in combination with irinotecan (CPT-11): Preliminary results of a multicenter phase II study. Proc Am Soc Clin Oncol 2000; 19:abstract 1260.

42 Ridwelski K, Kettner E, Florschütz A, Klein U, Eichelmann K, Lippert H: Final results of a phase I study of weekly gemcitabine and docetaxel in pancreatic carcinoma and preliminary results of a phase II study. Proc Am Soc Clin Oncol 2000;abstract 1256.

43 Jacobs AD, Otero H, Picozzi V Jr, Aboulafia DM, Weiden PL: A phase I/II study of gemcitabine $(\mathrm{G})$ and docetaxel (D) in patients (pts) with unresectable pancreatic cancer. Proc Am Soc Clin Oncol 2000;19:288a (abstract 1032).

44 Clark JW, Ryan DP, Kulke MH, Grossbard ML, Fuchs CS, Grossman SR, Morgan JA, Earle CC, Shivdasani R, Grenon N, Berg D, Mayer RJ: Phase II study of gemcitabine and docetaxel in patients with metastatic pancreatic cancer. Proc Am Soc Clin Oncol 2000;19: abstract 1238 .

45 Nelson AR, Fingleton B, Rothenberg ML, Matrisian LM: Matrix metalloproteinases: Biologic activity and clinical implications. J Clin Oncol 2000;18:1135-1149.

46 Carmichael J, Ledermann JA, Woll PJ, Gulliford T, Russel RC: Phase IB study of concurrent administration of marimastat and gemcitabine in non-resectable pancreatic cancer. Proc Am Soc Clin Oncol 1998; 17:232a (abstract 888).

47 Rosemurgy A, Buckels J, Charnley R, Winston R, Steward W, Staddon A, Curtis L, Rugg T, Rasmussen $\mathrm{H}$ and the marimastat in pancreatic cancer study group: A randomized study comparing marimastat to gemcitabine as first line therapy in patients with non-resectable pancreatic cancer. Proc Am Soc Clin Oncol 1999; 18:261a (abstract 1005)

48 British Biotech plc: Results of marimastat study 128: Pancreatic cancer monotherapy trial. Release date, 2/15/99. At http://www.britbio.co.uk/news/news_index.htm. 